\title{
Pluralismul religios ca provocare şi şansă în viziunea lui Karl Rahner
}

\author{
Jean NEDELEA
}

Abstract: The issue of pluralism - with all its range of accompanying issues - has entered the Romanian vocabulary of culture and theology particularly after the change of historical and social paradigm brought about by the December-1989 events. In this "brave new world", the "expertise" on pluralism and the solutions proposed by Rahner for the Christians' salvific cohabitation with a pluralist world might be a set of useful guidelines, without, however, being a canonical one. Such guidelines may be necessary in order to avoid, on the one hand, the defeatism and ghettoization of Christianity, and, on the other hand, a corrosive religious syncretism.

To the famous Jesuite theologian Karl Rahner (1904-1984), considered the most influential Catholic theologian of the $20^{\text {th }}$ century, religious diversity was never an abstract theological topic, but a reality of the world he lived in. While often meeting and confronting people with other faiths, Rahner knew how to respond with a Catholicism "open" to the challenges of religious pluralism. His writings on this topic gained a wide audience in the '60s and 70's of the last century, and his thinking enjoyed a wide publicity, both in the Church (through sermons) and in the media (through conferences and radio programs).

Keywords: religious pluralism, contemporaneity, denomination, postmodernity. 


\section{Introducere}

Pentru celebrul teolog iezuit Karl Rahner (1904-1984)', considerat cel mai influent teolog catolic al secolului al XX-lea, diversitatea religioasă nu a fost o temă teologică abstractă, ci o realitate a lumii în care a trăit. Întâlnindu-se şi confruntându-se adesea cu oameni de alte credințe, Rahner a ştiut să răspundă cu un „catolicism deschis" provocărilor pluralismului religios. Scrierile sale pe această temă au dobândit o largă rezonanţă în anii 60 şi 70 ai secolului trecut, iar gândirea lui s-a bucurat de o largă mediatizare eclesială (prin predici) şi publică (prin conferinţe şi emisiuni radio) ${ }^{2}$. Pluralismul religios a rămas pentru teologul german una dintre problemele cele mai dificile. Dar cu toate acestea, aşa cum remarca J. H. Fletcher, „este greu să numim un alt teolog care să fi influențat mai mult decât Karl Rahner discursul contemporan despre pluralismul religios"3.

Răspunzând invitaţiei de a veni la München în 1964, Rahner va deveni succesorul lui Romano Guardini la Catedra de Concepţia religioasă asupra lumii şi Filosofia religiilor. În această nouă conjunctură universitară, a avut un contact mai direct cu studenţii diverselor facultăţi şi a fost nevoit să reia mai atent, şi de o manieră mai abstractă, teme de filosofia religiilor tratate anterior. El va analiza acum locul şi rolul creştinului într-o societate marcată de pluralismul intelectual şi religios, problema raportului dintre creştinism şi religiile

${ }^{1}$ O prezentare cuprinzătoare a vieţii şi a operei lui Karl Rahner şi o evaluare concisă a teologiei lui am oferit în studiul „Un reprezentant al înnoirii teologiei catolice contemporane: Karl Rahner (1904-1984) - Repere bio-bibliografice şi scurte consideraţii asupra teologiei sale", în Anuarul Facultăţii de Teologie Ortodoxă „Patriarhul Justinian”, 2005, pp. 339-374.

${ }^{2}$ Cf. Jeannine Hill FLETCHER, „Rahner and religious diversity”, în The Cambridge companion to Karl Rahner, Declan Marmion, Mary E. Hines (eds.), Cambridge University Press, 2005, p. 235.

3 Jeannine Hill FLETCHER, „Rahner and religious diversity”, p. 235. Concepţia lui Rahner despre pluralism religios este încă, pentru Fletcher, un reper în dialogul teologic pe această temă: „De-a lungul ultimul sfert al secolului al XX-lea şi în noul mileniu, proiectul său teologic a influenţat în aşa fel dezbaterea, încât multe dintre vocile importante din teologia de astăzi intră în conversaţie directă cu el în ce priveşte diversitate religioasă prezentă". 


\section{Pluralismul religios ca provocare şi şansă}

în viziunea lui Karl Rahner

necreştine, ca şi diverse teme care făceau obiectul ecumenismului creştin $^{4}$.

Biserica, asemenea omului, trăieşte într-un timp pe care nu şi-1 alege. Analizând situaţia concretă şi contextul în care i-a fost dat Bisericii timpului său să trăiască, Rahner ia act de fenomenul pluralismului, fenomen care a caracterizat din plin lumea modernă şi, mai ales, postmodernă.

Atentă la semnele vremurilor, Biserica Romano-Catolică s-a confruntat cu delicata problemă a pluralismului, de la pluralismul cunoaşterii şi al disciplinelor teologice la cel religios şi spiritual.

Karl Rahner se numără printre primii teologi catolici care au analizat atent şi repetat fenomenul pluralismului ${ }^{5}$. El l-a evaluat din perspective variate, a cercetat atât cauzele, cât şi efectele lui, 1-a analizat raportându-l atât la creştinul individual, cât şi la comunitatea eclesială .

${ }^{4}$ Cf. Louis ROBERTS, Karl Rahner, sa pensée, son auvre, sa méthode, traduit de l'américain par Michel Martron, Mame, 1969, p. 207.

5 Vezi „Pluralismus”, în Kleines Theologisches Wörterbuch (în colaborare cu H. VORGRIMLER ), Freiburg, 1961, p. 290 şi în Lexikon für Theologie und Kirche. ed. a 2-a, Freibourg, 1963, pp. 566-567; „Grundzüge einer katholisch-dogmatischen interpretation der nichtchristlichen Religionen: Pluralismus, Toleranz und Christenheit", în Veröffentlichungen der Abendländischen Akademie, Nüremberg, 1961, pp. 55-74; „Zum heutigen Pluralismus in der geistigen Situation der Katholiken und der Kirche”, în Stimmen der Zeit, 176 (1965), pp. 191-199; „Über den Dialog in der plurallistischen Gesellschaft”, în Stimmen der Zeit, 176 (1965), pp. 321-330; „Kirchliches Lehramt und Theologie nach dem Konzil”, în Stimmen der Zeit, 178 (1966), pp. 404-420; „Die Gegenwart der Kirche. Theologische Analyse der Gegenwart als Situation des Selbstvollzugs der Kirche», în Handbuch der Pastoraltheologie, II/1 , Freibourg-Basel-Vienne, 1966, pp. 233-276; ,Zur Geschichtlichkeit der Theologie”, în Integritas, Geistliche Wandlung und menschliche Wirklichkeit, D. Stolte şi R. Wisser (Hrsg.), Tübingen, 1966, pp. 75-95; „Der Pluralismus der Theologie und die Einheit der Kirche”, în Concilium, 5 (1969), pp. 462-471; „,Der Glaube des Christen und die Lehre der Kirche”, în Stimmen der Zeit, 190 (1972), pp. 3-19.

${ }^{6} \mathrm{O}$ analiza atentă, însoţită de o evaluare critică a pluralismului în opera lui Rahner a făcut Albert RAFFELT: „Pluralismus - ein Plädoyer für Rahner und eine Bemerkung zur Sache", în volumul colectiv Gerhard Larcher, Klaus Müller, Thomas Pröpper (Hrsg.), Hoffnung, die Gründe nennt: Zu Hansjürgen Verweyens Projekt einer 


\section{Cauzele şi tipurile pluralismului}

Pentru celebrul teolog german, pluralismul contemporan nu este doar o realitate inevitabilă a lumii contemporane, ci este chiar un fenomen legitim ${ }^{7}$.

Cauzele pluralismului sunt văzute de Rahner în:

a) însăşi calitatea noastră de creatură;

b) condiţia postedenică a făpturii;

c) distanţa infinită între participarea la Misterul absolut şi obiectivarea sa categorială.

În conformitate cu cele trei cauze, Rahner expune trei tipuri de pluralism, pe care le-am putea numi:
a) pluralismul edenic;
b) pluralismul concupiscent postedenic;
c) pluralismul cunoaşterii.

\section{a) Pluralismul edenic}

Pluralismul, în sensul cel mai larg al termenului, cel de diversitate, este legat indisolubil de condiţia de creatură:

„există un pluralism autentic al realităţii. Acest pluralism al unei naturi diferite de Dumnezeu nu este doar aparenţa vidă îndărătul căreia realitatea - Unul, Absolutul, Dumnezeu - s-ar situa în aşa fel încât totul nu ar fi decât un nimic aparent sau că nu ar exista decât Dumnezeul absolut şi unic. Dacă creştinul mărturiseşte că Dumnezeu poate fi şi este în aşa fel Dumnezeu încât să poată face să existe un altul diferit de El în pluralitatea lui absolută şi incalculabilă, atunci el poate şi trebuie să se

erstphilosophischen Glaubensverantwortung, Friedrich Pustet, Regensburg, 1996, pp. 127-138.

${ }^{7}$ Cf. Karl RAHNER, Tratatul fundamental despre credinţă, trad. de Marius Taloş, Ed. Galaxia Gutenberg, Târgu-Lăpuş, 2005, pp. 12 şi 632, respectiv Gilles LANGEVIN, „Le pluralisme en matière spirituelle et religieuse selon Karl Rahner”, în Laval théologique et philosophique, vol. 29, n 1, 1973, pp. 3-4. 


\section{Pluralismul religios ca provocare şi şans̆} în viziunea lui Karl Rahner

expună senin şi cu încredere reală acestui pluralism al existenţei umane" $"$.

Încă înainte de Conciliul II Vatican, într-un studiu dedicat petrecerii timpului liber, Rahner semnalase că există un pluralism legat ireductibil de însăşi fiinţa omului ${ }^{9}$. De fapt, nu există doar un pluralism al creaţiei originare, ci şi un pluralism al interiorităţii celei mai adânci a omului. Acest pluralism lăuntric este justificat de dualismul ontologic care include spiritul şi materia, libertatea şi necesitatea, căci nici unul dintre elementele acestui dualism fiintial nu poate fi eliminat de celălalt, coexistând în sufletul omului ${ }^{10}$. Pluralismul acesta este, în opinia lui, indiciul condiţiei de creatură a lumii şi a omului. El există atât ca dat al lumii începuturilor, cât şi ca dat al interiorităţii umane. În cele din urmă, Dumnezeu Însuşi ,,a vrut acest pluralism al lumii Lui pentru ca omul să întrevadă tocmai prin aceasta că totul este învăluit în misterul divin" ${ }^{\prime 1}$. Diversitatea lumii ar ascunde şi ar trimite astfel permanent - în splendoarea pluralităţii ei - către unitatea ultimă a Misterului divin. Lumea, în intreaga ei pluralitate sau diversitate, ar fi deci o provocare şi o invitaţie la atotunitate adresată dintru început de Dumnezeu omului. Deşi „bună foarte”, creaţia „suspina” după unirea cu Ziditorul ei, unire care, ratată în Eden, se va realiza în actul Întrupării şi al unirii ipostatice şi, deplin, în vederea faţă către faţă a veacului viitor.

\section{b) Pluralismul postedenic}

Pluralismul lumii, însă, nu e doar rezultatul actului divin creator. Lumea e plurală nu doar pentru că aşa a dorit-o Dumnezeu, ci

\footnotetext{
${ }^{8}$ Karl RAHNER, Tratatul fundamental despre credinţă, p. 572.

9 Cf. Karl RAHNER, „Theologische Bemerkungen zum Problem der Freizeit", în Sämtliche Werke $(S W)$, Bd. 16, K. Lehmann, J. P. Metz, K. H. Neufeld, A. Raffelt, H. Vorgrimler (Hrsg.), Benzinger Verlag, Solothurn/Düsseldorf, Herder Verlag, Freiburg i. Br., 2005, p. 208. Opera completă apare după următorul plan editorial: I. Grundlegung, 1922-1949 (vol. 1-8); II. Aufbau, 1949-1964 (vol. 9-17); III. Entfaltung, 1964-1976 (vol. 18-26); IV. Sammlung 1977-1984 (vol. 27-32). Au mai rămas de publicat volumele 5 şi 32 .

${ }^{10}$ Cf. Karl RAHNER, ,Theologie der Macht”, în SW 12, p. 458.

${ }^{11}$ Karl RAHNER, Tratatul fundamental despre credinţă, p. 573.
} 
şi pentru că voinţa omului a introdus în lume păcatul şi separaţia. Fireşte, însă, una este diversitatea sau varietatea originară a lumii paradisiace şi alta este separaţia tensionată a lumii postedenice, căzute.

Printr-o cunoaştere concupiscentă, omul s-a îndepărtat de planul divin originar, viciind pluralitatea originară. Pluralismul paradisiac „,bun foarte” devine, prin păcatul omului, pluralismul plin de spini şi pălămidă al căderii. Păcatul a provocat, de asemenea, un pluralism intern turbulent, care este tot una cu o ,stare de dezintegrare” de neînlăturat, vizibilă atât în plan etic, cât şi în planul cunoaşterii ${ }^{12}$. Mozaicul, care reflecta unitar chipul lui Dumnezeu în om, a fost „dezintegrat” într-o multitudine de piese.

Dar această dezintegrare lăuntrică s-a extins, în mod firesc, şi asupra lumii, căci omul e ,un sistem deschis, permanent în comunicare cu lumea”, în vreme ce lumea nu e altceva decât „omul însuşi în extensiunea lui spaţio-temporală",13. Astfel, realitatea originară plurală devine, prin păcat, „realitate obscură, întunecoasă, de necuprins"14. Altfel spus, furişându-se în diversitatea impecabilă a începuturilor, păcatul a provocat pluralitatea pecabilă postedenică.

Şi omul şi lumea au în alcătuirea lor realităţi atât de diferite şi de diferenţiate încât omul singur nu poate, nici teoretic, nici practic, să unifice această diversitate şi multiplicitate în aşa fel încât să o poată înţelege şi stăpâni. Numai în Dumnezeu totul există în unitate, în vreme ce în lume, în istorie, există un permanent antagonism insurmontabil. Deşi existentă ca postulat metafizic al creaţiei, unitatea este un deziderat al făpturii şi orizontul eshatologic care animă permanent speranţa. Acest dor al creaţiei după unitate s-a împlinit istoric în Hristos, prin Întrupare, dar nu datorită strădaniei omului, ci datorită bunăvoinţei lui Dumnezeu. Definitiv şi eshatologic, însă, dorul acesta se va ostoi abia în veacul viitor, când Îl vom vedea pe Dumnezeu precum este. Doar atunci când El va fi „,totul în toate”, omul va afla - în

${ }^{12}$ Cf. Karl RAHNER, „Theologische Reflexionen zur Säkularization”, în $S W$ 24/1, p. 82.

${ }^{13}$ Karl RAHNER, „Theologische Reflexionen zur Säkularization”, în $S W 24 / 1$, pp. $82-$ 83.

${ }^{14}$ Karl RAHNER, Tratatul fundamental despre credinţă, p. 573. 


\section{Pluralismul religios ca provocare şi şansă}

în viziunea lui Karl Rahner

însăşi colocvialitatea tainică şi fără de sfârşit a Sfintei Treimi temeiurile ultime ale dialogului, dăruirii şi „toleranţei”" ${ }^{\prime 15}$.

În studiul său „Über das Latein als Kirchensprache” / „Despre latina ca limbă bisericească”, Rahner dă răspuns şi delicatei probleme a pluralităţii limbilor şi neamurilor. Pentru el, varietatea limbilor şi a neamurilor este deoptrivă expresia voinţei pozitive a lui Dumnezeu şi a separaţiei pecabile a oamenilor, expresia proniei pozitive de mântuire a lumii, a cărei împlinire este însă împiedicată de pluralismul antagonic al popoarelor. Acest pluralism antagonic va duce, în cele din urmă, la „o revoltă totală a unei părţi a umanităţii împotriva lui Dumnezeu" ${ }^{\prime 16}$.

Într-un alt studiu - „Dogmatischen Randbemerkungen zur Kirchenfrömmigkeit” / „Note marginale cu privire la evlavia bisericească" -, scris după încheirea Conciliului II Vatican, Rahner atrage atenţia asupra efectelor negative ale pluralismului asupra vieţii umane. La nivel individual, semnala el, omul „suferă până la ameninţarea fizică a vieţii sale din cauza pluralismului acestei lumi»"17. Iar la nivel social, datorită pluralismului, care a generat şi a accelerat secularizarea, perspectiva religioasă asupra lumii a încetat de a mai fi dominantă ${ }^{18}$.

\section{c) Pluralismul cunoaşterii}

A treia cauză a pluralismului, în viziunea lui Rahner, este caracterul finit, limitat al cunoaşterii Misterului divin de către om, distanţa dintre mărginirea cunoaşterii umane şi nemărginirea Absolutului divin. Dacă experienţa originară, paradisiacă, a omului presupunea participarea unitară, deşi nedeplină, a omului la întreaga realitate, experiența de după cădere presupune participarea „împrăştiată” a sa la nenumărate reprezentări fragmentare. Însăşi analogiile folosite de om pentru a vorbi despre Dumnezeu, ca şi cele folosite de Dumnezeu Însuşi pentru a ni Se descoperi sunt legate de

\footnotetext{
${ }^{15}$ Cf. Karl RAHNER, H. VORGRIMLER, Kleines Theologisches Wörterbuch, p. 290.

${ }^{16} S W 16$, p. 233.

${ }^{17} \mathrm{SW} 10$, p. 518.

${ }^{18}$ Cf. R. LENNAN, The Ecclesiology of Karl Rahner, Oxford University Press, 1995, p. 210.
} 
anumite locuri şi de anumite momente istorice. Variatele concepţii despre lume şi viaţă iş̧i au, în cele din urmă, originea în modurile foarte diferite de a percepe realul. În calitatea sa de „spirit în lume” (Geist in Welt), omul poate viza universalul la nivel abstract, transcendental, dar tot ceea ce realizează concret apare în limite specifice, istorice, categoriale. „Chiar şi concepţiile şi viziunile despre lume, fundamental universale, stau sub legile istoriei" ${ }^{\prime \prime}$. Şi cum legile istoriei sunt variate, nedepline, nestatornice şi schimbătoare (de la neam la neam şi de la vreme la vreme) este firesc să determine un pluralism legitim al cunoaşterii.

Să reţinem, în concluzie, că în prezentarea pe care o face pluralismului, Rahner

expune implicit sensurile acestuia, polisemia sa. Astfel, aşa cum am semnalat deja, pentru teologul iezuit există un pluralism voit de Dumnezeu, care este tot una cu diversitatea lumii paradisiace. Acest pluralism ţine de ontologia lumii, de condiţia ei de creatură, de finitudinea şi istoricitatea creaţiei (l-am numit pluralism edenic). El este tot una cu diversitatea voită şi creată de Dumnezeu. Există apoi un pluralism voit de om, din care nu lipsesc păcatul, separaţia şi antagonismul (pe care l-am numit pluralism postedenic). Şi, în cele din urmă, un pluralism gnoseologic, care însoţeşte atât pluralismul paradisiac, cât şi pluralismul postedenic. Rahner considera legitim pluralismul cunoaşterii pentru că în orice situaţie, în orice timp şi loc sar afla (în Eden sau în afara lui), omul este chemat să unifice în sine şi apoi în Dumnezeu pluralitatea de sensuri şi de raţionalităţi existente în lume. Iar acestă unificare o realizează în calitate sa de microcosm şi mediator.

\section{Pluralismul în teologie}

Deşi a analizat pluralismul în universalitatea lui, Rahner a pornit în demersul său de la pluralismul specific modernităţii şi mai ales postmodernităţii. „Omul recent” are tot mai acut impresia că istoria

${ }^{19}$ Karl RAHNER, „Über den Dialog in der pluralistischen Gesellschaft”, în $S W 15$, p. 358. 


\section{Pluralismul religios ca provocare şi şans̆ă}

în viziunea lui Karl Rahner

universală se derulează ca o istorie unică pentru toţi şi, prin urmare, că „fiecare a devenit vecinul fiecăruia, spre mai bine sau mai rău" ${ }^{20}$.

Pluralismul modern al cunoaşterii - fie că e vorba de cunoaşterea ştiinţifică, fie de cea filosofică - se reflectă, inevitabil, întro măsură semnificativă, în pluralismul teologiilor. Au apărut o pluralitate de teologii care nu mai pot fi integrate într-un sistem teologic monolitic:

„practic, teologia s-a fărâmiţat în nenumărate discipline, fiecare dintre acestea oferind un material enorm, cu o metodologie foarte diferenţiată şi dificilă, în timp ce păstrează extrem de puţine contacte cu celelalte discipline înrudite ori apropiate" ${ }^{21}$.

Pluralismul acesta teologic, ca stare de fapt, opina Rahner, nu poate fi depăşit nici prin activitatea comună a teologilor, prin aşa numitul Teamwork. Şi asta pentru că în ştiinţele spiritului autenticitatea unei afirmaţii depinde de experierea efectivă a ei. Ori tocmai trăirea şi participarea existenţială la adevăr nu prea este la îndemâna teologului ocupat şi cu alte discipline ${ }^{22}$.

În situaţia în care teologia este chemată să păstreze contactul cu multiplele filosofii şi antropologii, cu ştiinţele, dar şi cu „diversitatea vieţii spirituale neştiinţifice cultivate în artă, în poezie, în viaţa socială", este tot mai dificil să vorbim de o teologie atotcuprinzătoare şi ştiinţifică, întrucât ,ea însăşi a devenit o cantitate incomensurabilă de ştiinţe specifice" ${ }^{23}$.

În climatul pluralismului intelectual contemporan este evident că cineva care este bun cunoscător sau expert într-un domeniu este mai mult sau mai puţin ignorant în altul. Pentru a exemplifica această realitate, Rahner aminteşte cazul absolvenţilor de şcoli teologice. Tot în acest context, trimite şi la cazul lui Teilhard de Chardin, preot

${ }^{20}$ Karl RAHNER, „Über den Dialog in der pluralistischen Gesellschaft”, în $S W$ 15, p. 357.

${ }^{21}$ Karl RAHNER, Tratatul fundamental despre credinţă, p. 12.

${ }^{22}$ Cf. Karl RAHNER, Tratatul fundamental despre credinţă, p. 13.

${ }^{23}$ Karl RAHNER, Tratatul fundamental despre credinţă, p. 14. 
paleontolog, care trecea drept savant în ochii teologilor şi drept teolog în ochii savanţilor ${ }^{24}$. El sugerează, prin acest din urmă exemplu, că există riscul ca cei care se ocupă concomitent de domenii variate de studiu să locuiască, de fapt, în ,,ţara nimănui” şi să nu dobândească nici o competenţă specifică. Această stare de fapt, născută pe fondul exploziei ştiinţelor de azi şi, implicit, al pluralismului intelectual, este numită sugestiv de Louis Roberts „pilulă amară, dar inevitabilă" ${ }^{25}$. Apoi, desigur, datorită extinderii progresive a câmpului cunoaşterii, teologii contemporani nu mai pot face sintezele pe care le realizaseră odonioară un Cusa sau un Belarmin. Ei sunt invitaţi să recunoască „cu simplitate şi curaj” - că, în ciuda studiilor de teologie, rămân cu toţii nişte ignoranţi (rudes) ${ }^{26}$. Dar această recunoaştere onestă „nu ne autorizează în nici un fel să fim indolenţi [...] în faţa acestei responsabilități a speranţei şi a credinţei noastre" ${ }^{27}$.

Pluralismul teologic este vizibil şi în teme teologice foarte precis delimitate. Spre pildă, când vorbeşte de împlinirea finală a umanităţii, Rahner scrie că există o pluralitate a afirmaţiilor eshatologice referitoare la om, nemurirea sufletului, învierea în trup, starea intermediară, raportul dintre eshatologia individuală şi cea universală şi colectivă, şi că aceste afirmaţii nu pot fi uniformizate şi „,sintetizate într-un model reprezentativ plat" ${ }^{\text {, }}$.

O dată cu debutul Conciliul II Vatican, Biserica RomanoCatolică a încetat să mai formuleze noi definiţii doctrinare, realizând că ele nu mai pot fi unice şi că, în alcătuirea lor, este bine să se ţină seama de diversitatea specifică a neamurilor, a marilor spaţii culturale şi istorice, a confesiunilor şi a religiilor, pe de o parte, dar şi de vârsta şi pregătirea adresanţilor lor, pe de altă parte ${ }^{29}$.

\footnotetext{
${ }^{24}$ Karl RAHNER, „Kleine Frage zum heutigen Pluralismus in der geistigen Situation der Katholiken und der Kirche”, în $S W 15$, p. 348.

${ }^{25}$ Louis ROBERTS, Karl Rahner, sa pensée, son æuvre, sa méthode, p. 217.

${ }^{26} \mathrm{Cf}$. Karl RAHNER, Tratatul fundamental despre credinţă, p. 15. Rudes e un termen preluat de la Fericitul Augusti (De catechizandis rudibus) prin care sunt desemnaţi ignoranţii în domeniul teologiei.

${ }^{27}$ Karl RAHNER, Tratatul fundamental despre credinţă, p. 15.

${ }^{28}$ Karl RAHNER, Tratatul fundamental despre credinţă, p. 621.

${ }^{29}$ Cf. Karl RAHNER, Tratatul fundamental despre credinţă, pp. 633-634.
} 


\section{Pluralismul religios ca provocare şi şans̆ă în viziunea lui Karl Rahner}

Într-o lume a pluralismului confesional şi religios, Rahner recomandă smerenia, curajul, răbdarea şi moderaţia în zelul misionar. El le sugerează creştinilor să-şi reamintească că sunt „turma mică” şi că Biserica trăieşte deja în ,situaţie de Diaspora" ${ }^{\text {"3 }}$. Prezenţa lor în lume a reprezentat şi reprezintă permanent o, ,piatră de poticnire”. $\mathrm{Cu}$ toate acestea, creştinii nu trebuie să se mulţumească cu constatarea pluralismului ca un fenomen regretabil, ci să vestească permanent Evanghelia mântuirii. Prin această bunăvestire, pluralismul religios al pământului oamenilor poate fi sublimat în cerul lui Dumnezeu, unde Hristos va fi „totul în toate”. Această vestire să fie însă calmă şi bine temperată şi să evite fanatismul şi intoleranţa de orice fel ${ }^{31}$. Preoţilor li se recomandă să tragă şi consecinţe de natură personală pentru o bună plasare în viul pluralismului în care trăim. Spre pildă, să se ferească de pretenţia ipocrită de a fi atotcunăscători, pretenţie care poate cauza situaţii ridicole şi riscuri reale pentru viaţa Bisericii.

A recunoaşte şi a răspunde inteligent pluralismului a reprezentat provocarea cea mai stringentă pentru Catolicismul care a urmat Conciliului II Vatican. Într-un Apus în care pluralismul şi secularizarea câştigau tot mai mult teren, persepectiva religioasă asupra lumii devenea tot mai puţin dominantă. În acest context, Rahner propunea ca Biserica să se concentreze asupra aspectelor esenţiale ale credinţei creştine, având convingerea că aceste aspecte rămâneau în rezonanţă cu spiritul uman chiar şi într-o lume tot mai desacralizată. El susţinea că în viitor Biserica va fi chemată nu atât la o dezvoltare a doctrinei, cât la o înnoită trăire şi înţelegere a fundamentelor ei. „Domniei cantităţii" şi dominaţiei secularismului ar trebui să i se răspundă printr-un creștinism al calităţii, pe care să-1 definească

\footnotetext{
30 „Teologia transcendentală”, „creştinii anonimi” şi „situaţia de Diaspora” sunt expresiile care au consacrat teologia lui Rahner drept una dintre cele mai vii provocări ale gândirii creştine a secolului al XX-lea. Prin expresia „situaţia de Diaspora” expresie prin care teologul german descria prezenţa Bisericii în lumea pluralistă a modernităţii târzii -, teologul catolic desemna scăderea numărului creştinilor şi a influenţei lor asupra vieţii seculare.

${ }^{31}$ Cf. Karl RAHNER, ,Die Gegenwart der Kirche. Theologische Analyse der Gegenw art als Situation des Selbstvollzugs der Kirche", în Handbuch der Pastoraltheologie, II / 1 , Freibourg-in-Br., 1966, pp. 245-246.
} 
adâncirea existenţială în Misterul divin, apostolatul mistic şi o ,poezie creştină de rang”. Prin urmare, aprofundarea, ,din cercare”, a credinţei, iar nu simpla extensie a doctrinei ar fi de dorit. $\mathrm{Cu}$ alte cuvinte, astăzi este prioritară stimularea spiritualităţii transfiguratoare şi active, iar nu dobândirea unor cunoştinţe, fie ele şi înnoite, despre Dumnezeu ${ }^{32}$.

Iată, deci, că, în mod paradoxal, provocările pluralismului au solicitat creştinătăţii o concentrare asupra esenţialului ${ }^{33}$, identificat de teologul german cu Misterul. Iar concentrarea asupra Misterului oferă catolicismului contemporan şansa de a se elibera de raţionalism, de a îşi schimba şi înnoi structurile ecleziale (Strukturwandel der Kirche / Schimbarea structurii Bisericii este titlul unei lucrări „scandaloase” a teologului german) şi de a se adânci, poetic, în experierea Absolutului divin (pentru aceasta a propus Gebete des Lebens / Rugăciuni ale vieţii). Pluralismul este, prin urmare, nu doar o provocare, ci şi o şansă. Pe scurt, şansa purificării, esenţializării, adâncirii şi dinamizării credinţei.

În finalul Tratatului fundamental al credinţei, ,summa teologiei sale”, Rahner a răspuns provocării de esenţializare a credinţei creştine şi de reductio in misterium a ei. O face în trei formule teologice concise prin care încearcă să rezume întregul credinţei creştine şi să surprindă, pentru europeanul creştin de azi, ,esenţa intimă a istoriei mântuirii” ${ }^{34}$.

32 În acest sens, Papa Ioan Paul al II-lea era convins că „Biserica nu are nevoie, astăzi, de reformatori; ea are nevoie de sfinţi” (citat de Olivier CLÉMENT în „Cuvântul înainte" la cartea lui Vladimir ZIELINSKY, Dincolo de ecumenism, trad. de Carmen Dobre, Ed. Anastasia, Bucureşti, 1998, p. 10).

${ }^{33}$ Cf. R. LENNAN, The Ecclesiology of Karl Rahner, p. 211.

${ }^{34}$ Karl RAHNER, Tratatul fundamental despre credinţă, p. 636. Iată cele trei formule teologice propuse de Rahner:

1. Orizontul de necuprins al transcendenţei umane, care se concretizează în mod existenţial şi originar - se cheamă Dumnezeu şi se comunică în manieră existenţială şi istorică omului ca sarcină proprie în spiritul unei iubiri iertătoare. Culmea eshatologică a autocomunicării istorice a lui Dumnezeu, prin care această autocomunicare se revelează ca fiind învingătoare în mod ireversibil, se chemă Iisus Hristos. (pp. 636-637) 2. Omul parvine efectiv la sine însuşi printr-o împlinire de sine (Selbstvollzug) autentică doar atunci când se pune în joc în mod radical pe sine însuşi in favoarea celorlalţi. Atunci când face aceasta, el percepe (atematic sau explicit) ceea ce îţelegem prin Dumnezeu ca orizont, garanţie şi radicalitate a unei astfel de iubiri, (Dumnezeu) Care prin autocomunicare (existenţială şi istorică) Se face spaţiul 


\section{Pluralismul religios ca provocare şi şans̆ă în viziunea lui Karl Rahner}

Teologul iezuit este convins, însă, că formulele teologice de azi nu mai pot fi universale, „dată fiind diversitatea enormă a orizonturilor de înțelegere", şi că sunt necesare mai multe astfel de formule în Biserică „din cauza diversităţii situaţiilor în care trebuie vestită Evanghelia"35. De fapt, formulele teologice occidentale succinte - care vădeau „sentimentul de superioritate al colonialismului şi al imperialismului european” - nu mai pot fi exportate azi, întrucât „Occidentul însuşi, odinioară omogen, se fărâmiţează într-un pluralism intelectual şi cultural profund", fapt pentru care ,noi nu mai putem conta pe o teologie omogenă, unică şi identică" ${ }^{36}$ şi de aceea „va fi nevoie să tindem spre mai mult de o singură formulă de bază ${ }^{, 37}$.

Respiraţia pluralismul contemporan este dialogul şi în lipsa lui lumea de azi riscă să se sufoce. Epoca noastră, ca epocă a pluralismului, este, aşa cum nota Rahner, singura epocă a dialogului real ${ }^{38}$, a unui dialog care ar trebui să renunțe la tonul excesiv polemic pentru a face loc onestităţii intelectuale, încrederii şi deschiderii. Nu mai trăim în climatul societăţilor omogene, cu opinii exclusiviste, ghetoizante şi minoritare. Prin urmare, dialogul oferă azi unica poziţionare onestă, rezonabilă faţă de cei de altă credinţă, de alt neam sau de altă convingere, singura cale către o coexistenţă firească şi netulburată. În dialogul contemporan nimeni nu mai poate pretinde că deţine întreaga

posibilităţii acestei iubiri. Iubirea în cauză este înţeleasă în sens intim şi social şi constituie, în unitatea radicală a acestor două momente, fundamentul şi esenţa istorică. Această autocomunicare a lui Dumnezeu făcută omului, care susţine iubirea acestuia pentru aproapele, îş̧ are culmea istorică învingătoare din punct de vedere eshatologic in Iisus Hristos, care din acest motiv este iubit, cel puţin sub o formă anonimă în oricare alt om. (pp. 639-640)

3. Creştinismul este păstrarea deschisă (Offenhaltung) a întrebării cu privire la viitorul absolut, care vrea să se dăruiască tocmai ca atare prin autocomunicare, care şi-a fixat in mod eshatologic ireversibil voinţa în Iisus Hristos şi care se numeşte Dumnezeu. (p. 641)

${ }^{35}$ Karl RAHNER, Tratatul fundamental despre credinţă, p. 632.

${ }^{36}$ Karl RAHNER, Tratatul fundamental despre credinţă, p. 632.

${ }^{37}$ Karl RAHNER, Tratatul fundamental despre credinţă, p. 633.

${ }^{38}$ Rahner şi-a expus pe larg opinia sa despre dialog în „Über den Dialog in der pluralistischen Geselschaft", în Stimmen der Zeit 176 (1965), pp. 321-330 (SW 15, pp. 354-363). 
cunoaştere şi, de aceea, se cultivă, pentru prima dată, ideea că dialogul este o reală posibilitate de instruire pentru fiecare dintre interlocutori. Asta nu înseamnă, însă, că dialogul misionar n-ar mai viza nicicum convertirea celuilalt, şi că s-ar limita la a fi un simplu schimb amabil de idei. În acest din urmă caz, dialogul ar deveni pur şi simplu inutil şi lipsit de finalitate.

\section{Evaluare}

Aceste profunde şi incitante observaţii ale lui Karl Rahner despre viaţa Bisericii în postmodernitate şi despre strategiile ei de „acomodare” şi de vestire a mânturii într-o lume dominată de pluralism îşi păstrează încă actualitatea în teologia apuseană.

În cultura şi teologia românească, problematica pluralismului cu tot ,alaiul” ei de probleme - a pătruns mai ales după schimbarea de paradigmă istorică şi socială adusă de evenimentele din decembrie 1989.

În această „fericită lume nouă”, „expertiza” pluralismului şi soluţiile propuse de Rahner pentru convieţuirea mântuitoare a creştinilor cu o lume pluralistă ar putea fỉ un ghid necesar, fără a fi însă unul canonic. Un ghid necesar pentru a evita, pe de o parte, defetismul şi ghetoizarea creştinătăţii, iar, pe de altă parte, sincretismul religios dizolvant.

A refuza slujirea lumii pentru „lumirea” ei sau a confunda slujirea lumii cu slujirea lumescului ei sunt două atitudini creştine la fel de periculoase. Slujirea în adăvăr şi iubire a lumii este crucea creştinismului, crucea pe care S-a răstignit Domnul Hristos. Adevărul şi iubirea sunt verticala şi orizontala crucii, „virtuţile cardinale” ale răstignirii. A sluji doar în numele adevărului sau doar în numele iubirii înseamnă a nu mai sluji cruciform, a coborî de pe cruce şi, finalmente, a scoate crucea din creştinism. Iar când crucea este scoasă din creştinism, cum atenţiona Vl. Zielinski, creştinismul devine o religie pentru consumatori cucernici, un creştinism neascetic, neeclezial şi adogmatic. Un creştinism în care „taina fratelui” se înstrăinează de taina altarului, iar ethosului mântuirii i se substituie spaţiul non-transfigurării. 


\section{Pluralismul religios ca provocare şi şansă în viziunea lui Karl Rahner}

În evaluarea pe care o face teoriei rahneriene a „creştinilor anonimi”/ „creştinismului anonim” - potrivit căreia se pot mântui şi necreştinii, şi chiar şi ateii, dacă săvârşesc faptele iubirii milostive şi ascultă glasul revendicator al conştiinţei -, Urs von Balthasar identifică şi un punct slab: deschiderea radicală a Bisericii faţă de lume, faţă de necreştini şi necredincioşi. Or ,dacă esenţa veritabilă a creştinismului se raspândeşte în întreaga umanitate, «Bisericii lui Hristos», pentru a se diferenţia, nu-i mai rămâne decât forma, scheletul" şi va ajunge să se înţeleagă pe sine „ca «organizaţie» care susţine iradierea creştinismului de la sine înspre lume" ${ }^{\prime 39}$. Iar

„cu cât mai generos se deschide Biserica spre lume şi îi recunoaş̧e valorile, punându-le într-o lumină creştină, cu atât pare să îi rămână doar aspectul formei care îi răpeşte credibilitatea. Este astfel lovită din toate părţile, în structura ei exterioară, chiar şi acolo unde valorile creștine rămân, într-o oarecare măsură, valabile" ${ }^{\prime 40}$.

Dar, oare, există alternativă la deschiderea radicală a Bisericii faţă de lume? Poate fi conceput şi aplicat un alt gen de relaţie a Bisericii cu lumea, decât cel propus de Rahner şi asumat de tot mai mulţi creştini apuseni? Nu este creştinul chemat să participe la efortul comun de umanizare a omului?

Sigur, creştinul este dator să fie solidar cu tot ceea ce slujeşte binelui, dar sunt

situaţii în care proiectele seculare sunt potrivnice slujirii lumii în spirit creştin $^{41}$. Spre deosebire de Rahner care - în teoria „creştinismului anonim”, mai ales, dar şi în cea în care prezintă „Biserica în situaţia universală de Diaspora" - adoptă poziţia unei colaborări cât mai largi cu lumea, Balthasar păstrează un echilibru între slujirea oamenilor şi slujirea lui Dumnezeu, între progresişti şi

${ }^{39}$ Hans Urs von BALTHASAR, Trăind în slujba lui Dumnezeu, trad. de Marius Ivaşcu, Ed. Galaxia Gutenberg, Târgu-Lăpuş, 2008, p. 7.

${ }^{40}$ Hans Urs von BALTHASAR, Trăind în slujba lui Dumnezeu, p. 8.

${ }^{41}$ Cf. Hans Urs von BALTHASAR, Trăind în slujba lui Dumnezeu, p. 93. 
tradiţionalişti. Pentru teologul elveţian, implicarea creştinului „,pentru şi în lume", împreună cu Hristos, ţine de vocaţia apostolică a sa, dar atrage atenţia că această slujire a lumii trebuie să pornească de la slujirea lui Dumnezeu în Hristos şi să stea permanent ancorată în această slujire şi în dogmele fără de care creştinismul se depărtează de centru, de rodnicia originară ${ }^{42}$ şi de puterea sa de conservare şi de transfigurare a lumii. Căci, după cuvintele Domnului, „Voi sunteţi sarea pământului; dacă sarea se va strica, cu ce se va săra? De nimic nu mai e bună decât să fie aruncată afară şi călcată în picioare de oameni”" (Matei $5,13)$.

Balthasar constată însă că tensiunea între slujirea lui Dumnezeu şi slujirea lumii

„nu este provocată de creştin, ci de însăşi ambiguitatea lumii, care oscilează între condiţia sa de creatură bună şi închiderea de sine ostilă iubirii lui Dumnezeu: această tensiune este una constitutivă şi nu poate fi anulată în veacul acesta"43.

$\mathrm{Cu}$ toate acestea, Biserica este chemată să-şi reorienteze propriile structuri (ierarhice, sacramentale, canonice) către iubirea aproapelui ,printr-o autocritică mereu nouă în lumina judecăţii lui Hristos, pentru ca întreaga Biserică să devină mărturie pură a slujirii lui Dumnezeu în lume"44. Dar pentru ca acest deziderat să fie cu putinţă, Balthasar pleda ,pentru o Biserică săracă şi slujitoare (subl.m, J. N.), fiindcă e singura care mai poate garanta contactul cu lumea de azi, dar aceasta nu pentru a avea succes, ci pentru a-şi împlini misiunea”,45. Iar misiunea ei este aceea de a rămâne pe calea Fiului, pentru a nu risca rătăciri ,pe potecile iubirii autoinventate" 46 .

\footnotetext{
${ }^{42}$ Cf. Hans Urs von BALTHASAR, Trăind în slujba lui Dumnezeu, p. 109.

${ }^{43}$ Hans Urs von BALTHASAR, Trăind în slujba lui Dumnezeu, p. 94.

${ }^{44}$ Hans Urs von BALTHASAR, Trăind în slujba lui Dumnezeu, p. 92.

${ }^{45}$ Hans Urs von BALTHASAR, Trăind în slujba lui Dumnezeu, p. 101.

${ }^{46}$ Hans Urs von BALTHASAR, Trăind în slujba lui Dumnezeu, p. 106. Aici este vizată, desigur, teoria „creştinilor anonimi” a lui Rahner, după care se pot mântui şi necreştinii, şi chiar şi ateii, dacă săvârşesc faptele iubirii milostive şi ascultă glasul revendicator al conştiinţei.
} 


\section{Pluralismul religios ca provocare şi şans̆ă}

în viziunea lui Karl Rahner

Alternativa progresistă occidentală, al cărei reprezentant de marcă a fost Rahner, nu este, după Balthasar, nici atât de iminentă, cum s-a crezut adesea, şi nici unica alternativă. Răsăritul, spre pildă, oferă o altă alternativă, aşa cum ne descoperă mari scriitori ruşi (Alexandr Soljeniţîn, Daniel Siniavski, Mihail Bulgakov). Aceştia semnalează în operele lor că deşi Biserica ierarhică şi liturgică are o oarecare relevanţă încă, totuşi Biserica trăieşte viu în persoane şi grupuri restrânse, deşi periferice şi lipsite de influenţă majoră. În aceste persoane harismatice - care mai mult trăiesc decât propovăduiesc creştinismul şi din care iradiază lumina lui Hristos (căci nu i se poate interzice luminii să strălucească!) - opoziţia între viaţa creştină şi instituţia bisericească, între creştinism şi lume, între slujirea lui Dumnezeu şi slujirea oamenilor este depăşită ${ }^{47}$.

Dacă viziunea lui Rahner despre slujirea lumii este antropocentrică, pentru Balthasar slujirea lumii porneşte de la Dumnezeu şi trebuie să rămână permanent ancorată în Dumnezeu. Balthasar mărturisea că, în fapt, creştinismul nu este comunitatea pentru care Cuvântul „se iroseşte pentru a deveni o doctrină abstractă”, ca la Rahner, „ci este o prezenţă personală şi trinitară mereu vie în dragostea frăţească şi în comuniunea sacramentală şi existenţială" ${ }^{48}$. Teologul elveţian a mărturisit şi foarte deschis că spre deosebire de Rahner, care crede în pluralism datorită pesimismului său, el crede în catolicitate ${ }^{49}$.

Ori de câte ori Ortodoxia, la răscruce ca şi astăzi, purtând crucea discernământului, a ales discernământul crucii (adică asceza personală întru slujirea adevărului până la jertfa martirică), s-a păstrat pe calea cea strâmtă care duce la viaţă. Martirii şi sfinţii ei, prigoniţi până azi pentru adevăr şi dreptate - teologhisind şi călăuzind prin fapta iubirii întru adevăr, iar nu cu vorbe meşteşugite şi cu „salvatoare” compromisuri -, ne oferă trezvia şi discernământul necesare unei izbăvitoare deosebiri a duhurilor care bântuie lumea de azi şi adierea de bun miros care ar putea să împrăştie „fumul lui Satan” care, după

${ }^{47}$ Cf. Hans Urs von BALTHASAR, Trăind în slujba lui Dumnezeu, pp. 8-9.

${ }^{48}$ Hans Urs von BALTHASAR, Trăind în slujba lui Dumnezeu, p. 109.

${ }^{49}$ Hans Urs von Balthasar despre opera sa, trad. de Wilhelm Tauwinkl, Ed. Galaxia Gutenberg, Târgu-Lăpuş, 2005, p. 110. 
mărturisirea Papei Paul al VI-lea, „s-a strecurat în templul Domnului" ${ }^{50}$.

Dacă iubirea de Dumnezeu va pironi din nou pe cei credincioşi pe Crucea lui Hristos şi va face, astfel, din ei martori, atunci nici pluralismul şi nici postmodernitatea relativizantă nu vor putea instaura „religia umanistă şi vagă în care Dumnezeu devine o prelungire a omului care îl caută ${ }^{, 51}$. Prin sfinți, martiri şi mărturisitori, lumii i se va vesti permanent că Hristos a înviat şi că viaţa nu este închisă în cimitirele istoriei, ci peregrinează pe calea înveşnicirii ei eshatologice.

${ }^{50}$ Vladimir ZIELINSKY, Dincolo de ecumenism, trad. de Carmen Dobre, Ed. Anastasia, Bucureşti, 1998, p. 44.

${ }^{51}$ Vladimir ZIELINSKY, Dincolo de ecumenism, p. 28. 